\title{
Development and characterization of microsatellite loci for common raven (Corvus corax) and cross species amplification in other Corvidae
}

\author{
Christin L. Pruett ${ }^{1 *}$, Leping Wan ${ }^{1}$, Tianyu Li ${ }^{1}$, Cory Spern' ${ }^{1}$, Stacey L. Lance ${ }^{2}$, Travis Glenn ${ }^{3}$, Brant Faircloth ${ }^{4}$ \\ and Kevin Winker ${ }^{5}$
}

\begin{abstract}
Background: A priority for conservation is the identification of endemic populations. We developed microsatellite markers for common raven (Corvus corax), a bird species with a Holarctic distribution, to identify and assess endemic populations in Alaska.

Results: From a total of 50 microsatellite loci, we isolated and characterized 15 loci. Eight of these loci were polymorphic and readily scoreable. Eighteen to 20 common ravens from Fairbanks, Alaska were genotyped showing the following variability: $3-8$ alleles per locus, $0.25-0.80$ observed heterozygosity $\left(H_{0}\right)$, and $0.30-0.80$ expected heterozygosity $\left(\mathrm{H}_{\mathrm{e}}\right)$. All loci were in Hardy-Weinberg equilibrium and linkage equilibrium and many loci amplified and were polymorphic in related taxa.

Conclusions: These loci will be used to identify endemic populations of common raven and assess their genetic diversity and connectivity.
\end{abstract}

Keywords: Corvus, PCR primers, Microsatellite, Holarctic, Alaska

\section{Findings}

Common raven (Corvus corax) is a widespread, Holarctic bird that is listed as least concern on the IUCN Red List of Threatened Species (http://www.iucnredlist.org/ search). Although common ravens in Alaska are not morphologically diverse (2 subspecies) [1], genetic assessments using mitochondrial DNA markers have shown differences among lineages [2] and have suggested that isolated, endemic populations are found in the Aleutian Islands of Alaska [3]. Island populations were possibly isolated in glacial refugia as has been suggested in other studies of Aleutian landbirds [3-6]. Alternatively, populations might be post-glacial in origin having colonized

\footnotetext{
*Correspondence: cpruett@fit.edu

'Department of Biological Sciences, Florida Institute of Technology,

Melbourne, FL 32901, USA

Full list of author information is available at the end of the article
}

after the last glacial maximum $(\sim 15,000 \mathrm{ybp})[7]$. Given the recent timing of these events, a quickly evolving molecular marker is needed to assess the genetic diversity of populations, connectivity among populations, and to understand the history of ravens throughout the Holarctic. We developed eight microsatellite loci that will be used to assess population structure, rates of gene flow, colonization history, and to identify isolated populations of common raven.

Total genomic DNA was extracted from the muscle tissue of two common ravens from Alaska using a QiAamp DNA Mini Kit (Qiagen, Valencia, CA). The protocols of Glenn and Schable [8] and Katzinel et al. [9] were used to isolate microsatellite loci. Briefly, restriction enzymes were used to digest DNA, adapters were ligated onto fragments, microsatellite-containing fragments were separated using biotinylated probes and streptavidin beads, and fragments yields were increased using PCR. 


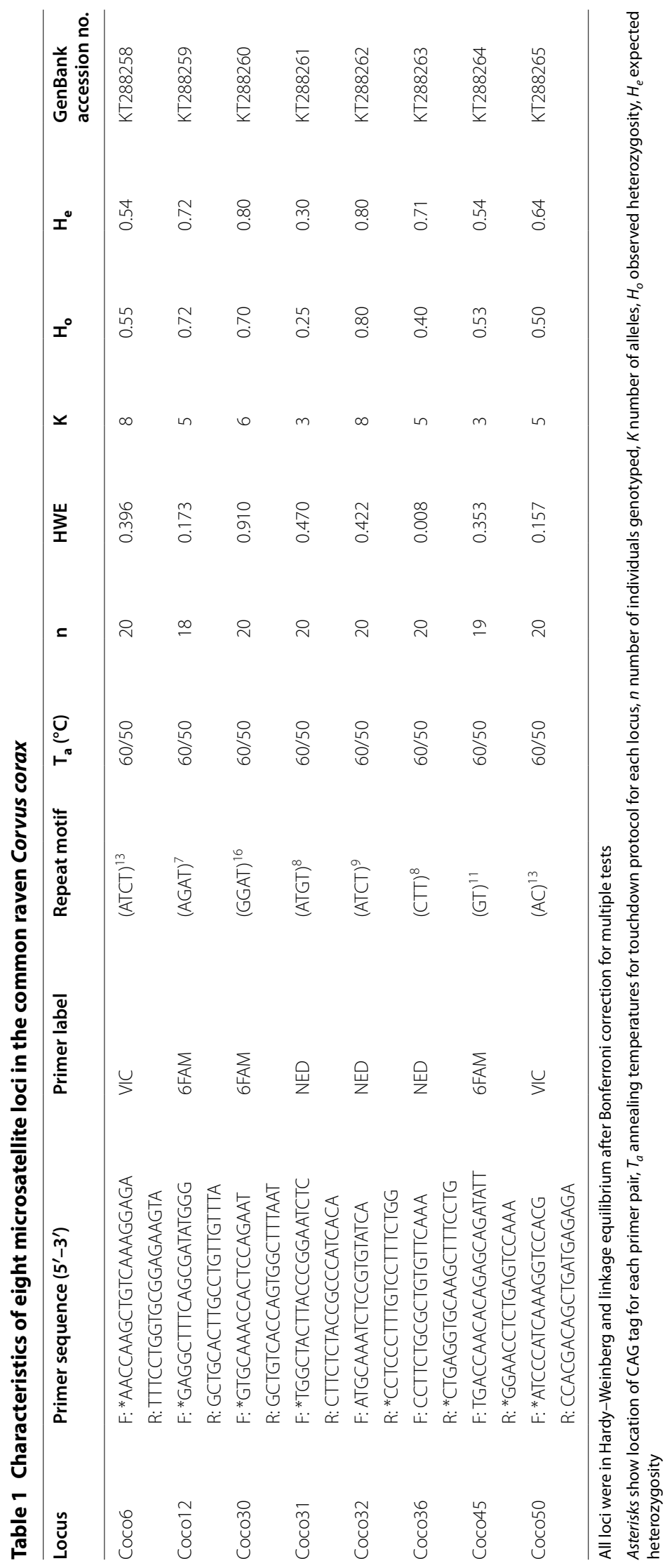


Fragments were run on a Roche 454 FLX with Titanium chemistry (454 Life Sciences, a Roche Company, Branford, CT) with similarly treated libraries, each with combinations of unique adapter and Roche MID-tags. We used demuxipy (https:/github.com/faircloth-lab/ demuxipy/) to demultiplex fragments, and used a version of MSATCOMMANDER [10] to find 591 sequences containing microsatellites from 1467 sequence reads. Primer 3 [11] was used to design primers with the CAG primer sequence (5'-CAGTCGGGCGTCATCA-3') prepended to the $5^{\prime}$ end of one primer of each pair. This enables the use of a fluorescently labeled primer with the CAG sequence during PCR to tag amplified fragments $[12,13]$. A short sequence (GTTT) was prepended to the primer without the CAG sequence to encourage adenylation of the amplicons for accurate genotyping $[14,15]$.

Fifty primer pairs were tested for amplification and polymorphism using the DNA from 10 individuals. Amplifications were in $20 \mu \mathrm{l}$ volumes [ $250 \mu \mathrm{g} / \mathrm{mL}$ BSA, $10 \times$ Buffer B (Fisher Scientific), $25 \mathrm{mM} \mathrm{MgCl}, 5 \mu \mathrm{M}$ unlabeled primer, $0.5 \mu \mathrm{M}$ tag labeled primer, $5 \mu \mathrm{M}$ universal dyelabeled primer, $2.5 \mathrm{mM}$ dNTPs, 0.5 units Taq DNA polymerase (Fisher Scientific), and 20 ng DNA template] using a BioRad MyCycler thermal cycler. Touchdown cycling conditions were used to amplify DNA and for attachment of the universal dye-labeled primer with the CAG tag. PCR parameters included an initial denaturation step of 2 min $30 \mathrm{~s}$ at $95^{\circ} \mathrm{C}$ then 20 cycles of $95^{\circ} \mathrm{C}$ for $20 \mathrm{~s}, 65^{\circ} \mathrm{C}$ to $50{ }^{\circ} \mathrm{C}$ annealing temperature for $20 \mathrm{~s}$ (decreasing $0.5^{\circ} \mathrm{C}$ per cycle), and extension step of $72{ }^{\circ} \mathrm{C}$ for $30 \mathrm{~s}$ followed by 15 cycles of $95^{\circ} \mathrm{C}$ for $20 \mathrm{~s}, 55^{\circ} \mathrm{C}$ to $45^{\circ} \mathrm{C}$ for $20 \mathrm{~s}$, and $72{ }^{\circ} \mathrm{C}$ for $30 \mathrm{~s}$. Cycles were followed with a final extension step of $72{ }^{\circ} \mathrm{C}$ for $10 \mathrm{~min}$. An ABI3730XL sequencer (Applied Biosystems) was used to determine genotypes. We found that fifteen primers amplified a product and eight of these primers exhibited polymorphism.

Initially, we tested for polymorphism using ten individuals from seven locations in Alaska including locations from the Aleutian Islands, the mainland of Alaska, and islands in southeast Alaska. Herein, we report the statistics associated with polymorphic loci using 18-20 individuals from Fairbanks, Alaska to avoid any Wahlund effect caused by population structure [16]. We also tested the polymorphism of one to three individuals each for seven other species in the family Corvidae (Tables 1,2) to assess cross-species amplification. We used Gene Mapper software (Applied Biosystems) to score alleles and to determine the number of alleles per locus $(\mathrm{K})$, observed heterozygosity $\left(\mathrm{H}_{\mathrm{o}}\right)$, and expected heterozygosity $\left(\mathrm{H}_{\mathrm{e}}\right)$, using Arlequin ver. 3.5 [17]. We also tested for HardyWeinberg equilibrium and linkage disequilibrium using Arlequin and used Microchecker [18] to test for genotyping errors. We found that the number of alleles per locus ranged from 3 to $8, \mathrm{H}_{\mathrm{o}}$ ranged from 0.25 to 0.80 , and $\mathrm{H}_{\mathrm{e}}$ ranged from 0.30 to 0.80 for common ravens (Table 1). All loci were in Hardy-Weinberg equilibrium and linkage equilibrium after correction for multiple tests and we found no evidence of null alleles, stuttering, or largeallele dropout.

Preliminary data from nine Alaska populations of common raven showed that the loci developed in this study are useful for population-level assessments with pairwise FST values ranging from 0.011 to 0.51 . In addition, these loci are polymorphic in these populations $\left(\mathrm{H}_{\mathrm{e}} 0.40-0.74\right.$; alleles per locus, 2.88-6.75). Eight loci that were developed for other Corvidae have shown polymorphism in common raven [19]. By combining our newly developed markers with those from other taxa, it is possible that researchers could assess very fine-scale population structure.

In other Corvidae taxa, we found that the majority of loci amplified and were polymorphic in six of the seven species (Table 2). All loci amplified in the fish crow (Corvus ossifragus) and five of eight loci were polymorphic. Loci that were monomorphic in other taxa might be polymorphic if a larger sample size was assessed. We suggest

Table 2 Number of alleles in eight microsatellite loci in seven Corvidae species

\begin{tabular}{|c|c|c|c|c|c|c|c|c|c|}
\hline \multirow[t]{2}{*}{ Species } & \multirow[t]{2}{*}{$\mathbf{n}$} & \multicolumn{8}{|c|}{ Number of alleles per locus } \\
\hline & & Coco6 & Coco12 & $\operatorname{Coco30}$ & Coco31 & Coco32 & Coco36 & Coco45 & $\operatorname{Coco50}$ \\
\hline Fish crow (Corvus ossifragus) & 2 & 4 & 1 & 3 & 1 & 3 & 2 & 2 & 1 \\
\hline Northwestern crow (Corvus caurinus) & 2 & - & - & 3 & 1 & 1 & 3 & 3 & 1 \\
\hline American crow (Corvus brachyrhynchos) & 1 & - & - & 2 & 2 & 1 & 2 & 1 & 1 \\
\hline Steller's jay (Cyanocitta stelleri) & 3 & - & - & 2 & 1 & - & 2 & 1 & 3 \\
\hline Blue jay (Cyanocitta cristata) & 2 & - & - & 3 & 2 & - & 2 & 1 & 2 \\
\hline Gray jay (Perisoreus canadensis) & 2 & - & - & 3 & 1 & 4 & 1 & 1 & 2 \\
\hline Florida scrub-jay (Aphelocoma coerulescens) & 3 & - & - & - & - & - & - & - & - \\
\hline
\end{tabular}

$n$ number of individuals attempted to amplify and genotype, - individuals failed to amplify at locus 
that these loci could be successfully used for populationlevel assessments in these species (Table 2) and possibly in other members of the genera Corvus and Perisoreus but are unlikely to be useful in Aphelocoma (Table 2).

\section{Availability of the supporting data}

Microsatellite sequences were deposited in the National Center for Biotechnology Information (http://www.ncbi. nlm.nih.gov). They are accessible via GenBank accession numbers listed in Table 1.

\section{Authors' contributions}

SL, TG, and BF developed and identified the microsatellite loci. LW, TL, and CS identified polymorphic loci and genotyped samples used in this manuscript. KW performed field work and provided DNA samples of ravens. CLP analyzed the data and wrote the manuscript. All authors read and approved the final manuscript.

\section{Author details \\ 1 Department of Biological Sciences, Florida Institute of Technology, Melbourne, FL 32901, USA. ${ }^{2}$ Savannah River Ecology Laboratory, University of Georgia, Aiken, SC 29802, USA. ${ }^{3}$ Department of Environmental Health Sci- ence, University of Georgia, Athens, GA 30602, USA. ${ }^{4}$ Department of Biological Sciences, Louisiana State University, Baton Rouge, LA 70803, USA. ${ }^{5}$ University of Alaska Museum, University of Alaska Fairbanks, Fairbanks, AK 99775, USA.}

\section{Acknowledgements}

This work was supported by the Florida Institute of Technology, University of Alaska Museum, and by the U. S. Department of Energy under award number DE-FC09-07SR22506 to the University of Georgia Research Foundation.

\section{Competing interests}

The authors declare that they have no competing interests.

\section{Ethics statement}

Methods for obtaining samples for this research used the procedures outlined in "Guidelines to the Use of Wild Birds in Research" published by The Ornithological Council (http://www.nmnh.si.edu/BIRDNET/quide/index.html). These guidelines are the appropriate standard for Animal Welfare Act compliance. Bird sampling was approved by the University of Alaska Institutional Animal Care and Use Committee and in compliance with permits from state and federal wildlife agencies.

Received: 17 July 2015 Accepted: 27 October 2015

Published online: 06 November 2015

\section{References}

1. Gibson DD, Kessel B. Inventory of the species and subspecies of Alaska birds. West Birds. 1997;28:45-95.
2. Omland KE, Tarr CL, Boarman WI, Marzluff JM, Fleischer RC. Cryptic genetic variation and paraphyly in ravens. Proc Royal Soc Lond B. 2000;267:2475-82.

3. Pruett $\mathrm{CL}$, Winker K. Evidence for cryptic northern refugia among highand temperate-latitude species in Beringia - a response to Stewart and Dalen (2008). Clim Change. 2008;38:23-7.

4. Holder K, Montgomerie R, Friesen VL. Glacial vicariance and historical biogeography of rock ptarmigan (Lagopus mutus) in the Bering region. Mol Ecol. 2000;9:1265-78.

5. Pruett CL, Winker K. Biological impacts of climatic change on a Beringian endemic: cryptic refugia in the establishment and differentiation of the rock sandpiper (Calidris ptilocnemis). Clim Change. 2005;68:219-40.

6. Pruett CL, Turner TN, Topp CM, Zagrebelny S, Winker K. Divergence in an archipelago and its conservation consequences in rock ptarmigan. Conserv Genetics. 2010;11:241-8.

7. Pruett CL, Winker K. Northwestern song sparrow populations show genetic effects of sequential colonization. Mol Ecol. 2005;14:1421-34.

8. Glenn TC, Schable NA. Isolating microsatellite DNA loci. Methods Enzymol. 2005;395:202-22.

9. Kartzinel TR, Trapnell DW, Glenn TC. Microsatellite primers for the Neotropical epiphyte Epidendrum firmum (Orchidaceae). Am J Bot. 2012:99:e450-2.

10. Faircloth BC. MSATCOMMANDER: detection of microsatellite repeat arrays and automated, locus-specific primer design. Mol Ecol Resour. 2008:8:92-4.

11. Untergasser A, Cutcutache I, Koressaar T, Ye J, Faircloth BC, Remm N, Rozen SG. Primer3-new capabilities and interfaces. Nucl Acids Res. 2012:40:e115.

12. Schuelke M. An economic method for the fluorescent labeling of $P C R$ fragments. Nat Biotech. 2000;18:233-4.

13. Hauswaldt JS, Glenn TC. Microsatellite DNA loci for the diamondback terrapin (Malaclemys terrapin). Mol Ecol Resour. 2003;3:174-6.

14. Brownstein MJ, Carpten JD, Smith JR. Modulation of non-templated nucleotide addition by Taq DNA polymerase: primer modifications that facilitate genotyping. Biotechniques. 1996;20:1004-10.

15. Traxler B, Brem G, Muller M, Achmann R. Polymorphic DNA microsatellites in the domestic pigeon, Columba livia var. domestica. Mol Ecol. 2000;9:366-8.

16. Hartl DL, Clark AG. Principles of population genetics. 4th ed. Sunderland: Sinauer Associates; 1997.

17. Excoffier L, Laval G, Schneider S. Arlequin ver. 3.0: an integrated software package for population genetics data analysis. Evol Bioinforma Online. 2005; 1:47-50.

18. Van Oosterhout C, Hutchinson WF, Wills DPM, Shipley P. Micro-checker: software for identifying and correcting genotyping errors in microsatellite data. Mol Ecol Notes. 2004;4:535-8.

19. Fleischer RC, Boarman WI, Gonzalez EG, Godinez A, Omland KE, Young S, Helgen L, Syed G, McIntosh CE. As the raven flies: using genetic data to infer the history of invasive common raven (Corvus corax) populations in the Mojave Desert. Mol Ecol. 2008;17:464-74.

\section{Submit your next manuscript to BioMed Central and take full advantage of:}

- Convenient online submission

- Thorough peer review

- No space constraints or color figure charges

- Immediate publication on acceptance

- Inclusion in PubMed, CAS, Scopus and Google Scholar

- Research which is freely available for redistribution 